\title{
Janusz SŁODCZYK*
}

\section{TRADYCJE URBANIZACYJNE NA OBSZARZE AFRYKI SUBSAHARYJSKIEJ}

\author{
TRADITIONS OF URBANISATION IN SUB-SAHARAN AFRICA
}

\begin{abstract}
NR DOI: $10.25167 / \mathrm{sm} 2018.032 .01 \quad$ s. 9-20
ABSTRAKT: W artykule skoncentrowano się na tradycjach budowy i przestrzennej formie miast w Afryce Subsaharyjskiej w okresie przedkolonialnym oraz na przeobrażeniach miast afrykańskich, które dokonały się w czasach kolonialnych. Przypomniano najstarsze, rozwijające się przed naszą erą cywilizacje miejskie Afryki, jak Aksum i Meroe, a następnie sięgające czasów średniowiecza Wielkie Zimbabwe na południu Afryki oraz Timbuktu i Djenne w Afryce Zachodniej. Omówiono różne układy przestrzenne występujące w miastach na południe od Sahary. W okresie kolonialnym planowanie urbanistyczne podporządkowane było zasadzie segregacji przestrzennej różnych w sensie etnicznym i kulturowym grup ludności. Zwrócono uwagę na wpływ sposobu zarządzania kolonią na przestrzenną strukturę miast. Przedstawiono materiały potwierdzające fakt, że okres kolonialny był czasem przyspieszonej urbanizacji krajów afrykańskich.
\end{abstract}

SŁOWA KLUCZOWE: urbanizacja, planowanie miast, Afryka Subsaharyjska

ABSTRACT: The article focuses on the traditions of construction and spatial form of cities in Sub-Saharan Africa in the pre-colonial period and on the transformations of African cities that took place in the colonial times. The oldest urban civilizations of Africa, like Aksum and Meroe are recalled, followed by the Great Zimbabwe in the Middle Ages in southern Africa, Timbuktu and Djenne in West Africa. Various spatial systems occurring in cities south of the Sahara are discussed. During the colonial period, urban planning was subordinated to the principle of spatial segregation of various population groups in the ethnic and cultural sense. Attention was drawn to the influence of the colony management method on the spatial structure of cities. Materials were presented confirming the fact that the colonial period was a time of accelerated urbanization of African countries.

KEY WORDS: urbanisation, urban planning, Sub-Saharan Africa

\section{Wprowadzenie}

Tradycje urbanistyczne Afryki Subsaharyjskiej są rzadko podejmowane w polskiej literaturze z zakresu geografii miast i historii urbanistyki. Z oczywistych względów problemy rozwoju miast na terenach na południe od Sahary są znacznie częściej

\footnotetext{
* Uniwersytet Opolski, Wydział Ekonomiczny, e-mail: jslod@uni.opole.pl
} 
przedmiotem zainteresowania badaczy z krajów, które były mocarstwami kolonialnymi. Celem artykułu jest wskazanie, że tradycje budowy ośrodków miejskich w różnych częściach Afryki są długie, bogate i różnorodne. Jednocześnie w artykule starano się wykazać, że relatywnie krótki okres kolonialny w zasadniczy sposób wpłynął na lokalizację, formę przestrzenną i strukturę miast Afryki Subsaharyjskiej. W artykule nawiązano do najstarszych cywilizacji miejskich omawianego obszaru, następnie na wybranych przykładach starano się przedstawić wpływ kontaktów z Europejczykami na formę miast w okresie przedkolonialnym i określić skutki głównych zasad, którym podporządkowane było planowanie miast w okresie kolonialnym.

\section{Ośrodki miejskie w Afryce Subsaharyjskiej w czasach przedkolonialnych}

Pod względem tradycji urbanizacyjnych kontynent afrykański jest bardzo zróżnicowany. Historia budowy miast w Afryce Północnej jest zupełnie inna niż w Afryce Subsaharyjskiej.

Tradycje miejskie Afryki Północnej wiążą się z cywilizacją egipską, gdzie już ponad 3000 lat p.n.e. istniało Nekhen będące ważnym ośrodkiem miejskim. Potem cały region rozwijał się pod wpływem cywilizacji antycznych. Szczególnie dużo miast powstało i rozwinęło się w czasach Imperium Rzymskiego. Od VII w. Afryka Północna znalazła się w kręgu cywilizacji arabskiej, co zasadniczo zmieniło charakter i wygląd miast tego obszaru. Miasta Afryki Północnej charakteryzują się cechami typowymi dla miast islamskich.

Na południe od Sahary tradycje budowy miast nie są tak bogate, niemniej w różnych regionach i w różnych okresach powstawały ważne centra o charakterze miejskim. Do najważniejszych przykładów cywilizacji miejskich w Afryce Subsaharyjskiej należą: w Afryce Wschodniej - Meroe na terenie dzisiejszego Sudanu, Aksum w Etiopii, w Afryce Zachodniej Kumbi Saleh, Timbuktu, Djenne, miasta-państwa zakładane przez lud Joruba (na terenie dzisiejszej Nigerii), królestwo Benin, imperium Kongo, a także Wielkie Zimbabwe na południu kontynentu (ryc. 1).

W V w. p.n.e. założone zostało Aksum będące stolicą pierwszego państwa etiopskiego. Około roku 356 władca Aksum przyjął chrześcijaństwo, a miasto dla Kościoła etiopskiego jest do dziś miejscem świętym, gdzie według tradycji przechowywana jest Arka Przymierza. Było ono ważnym ośrodkiem handlu, a jego władcy kontrolowali dwa porty na Morzu Czerwonym, na szlaku z Imperium Rzymskiego do Indii. Znakomite położenie zapewniało miastu pomyślność gospodarczą. Po blisko tysiącletnim trwaniu ok. VII w. miasto zaczęło stopniowo podupadać, co wiązało się z odcięciem go przez Arabów od szlaków handlowych prowadzących w stronę Bizancjum i Aleksandrii.

Aksum spełniało funkcje gospodarcze, ale jednocześnie było centrum ceremonialnym. Ściany domów budowano z kamienia okładanego mułem i przekładanego ozdobnymi belkami. Centralny pawilon, w którym znajdowały się dekorowane malowidłami sale z kolumnami, otoczony był przez mniejsze budynki. Pałace części centralnej ota- 


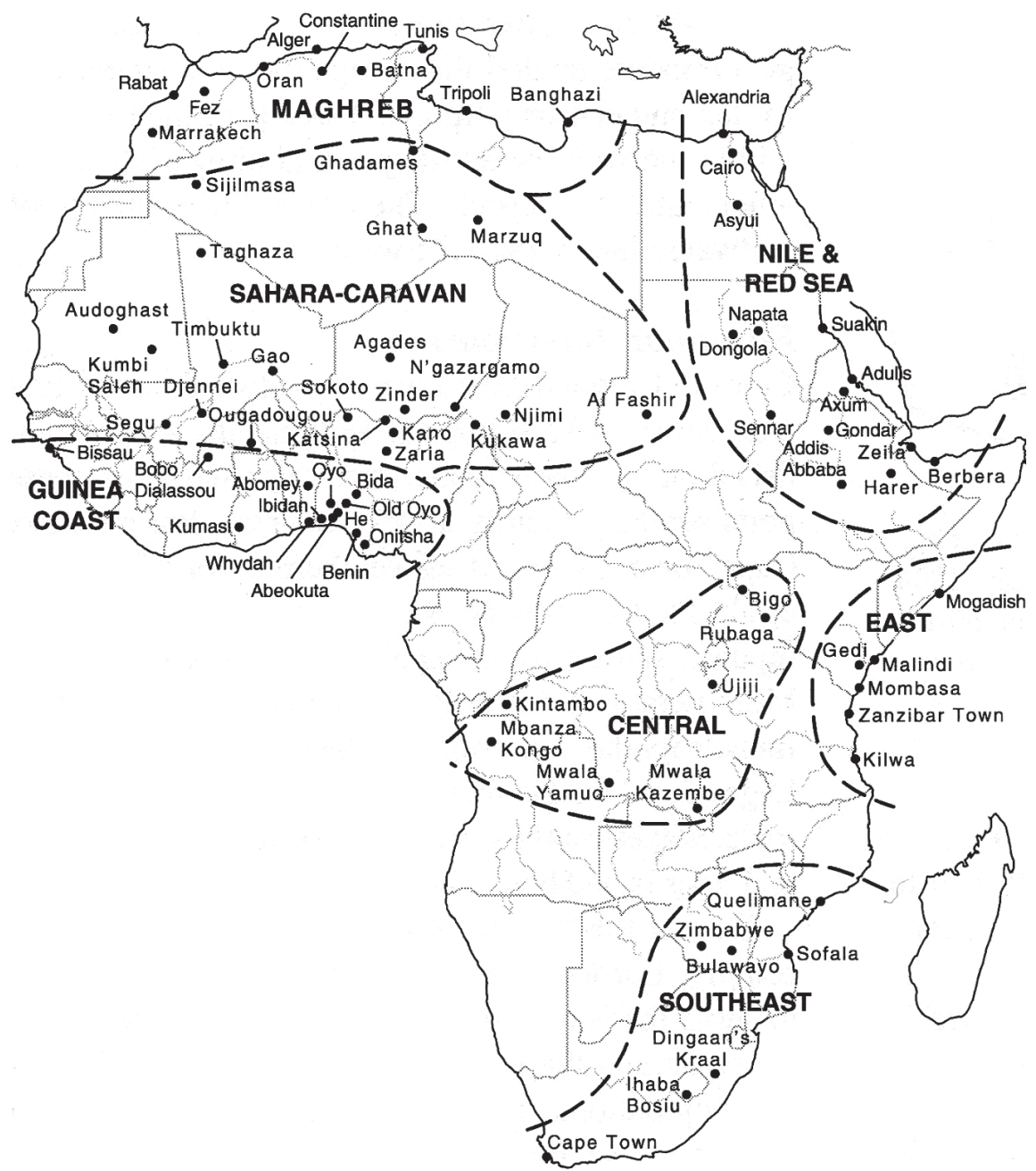

Ryc. 1. Historyczne ośrodki urbanizacji w Afryce przed kolonizacją

Źródło: Mehretu 1993 (za: Kaplan, Wheeler, Holloway 2004).

czały dzielnice podmiejskie, których mieszkańcy zamieszkiwali kryte strzechą domy z mułu i kamienia (Windmuller-Luna 2015). Pozostałością i świadectwem niezwykłej architektury Aksum są stele, ogromne obeliski z różnych okresów - najwyższy powstał 1700 lat temu. Pozostałości królewskich grobowców i pałaców pochodzą z IV i VI w.

W okresie między 800 r. p.n.e. a 350 r. n.e. na terenie północnej części dzisiejszego Sudanu rozwinęła się ważna metropolia Meroe, która od 300 r. p.n.e. była stolicą królestwa Kusz. Położone na wschodnim brzegu Nilu na ważnym szlaku handlowym Meroe było przez długi czas silnym ośrodkiem handlowym i produkcyjnym. Szczególne znaczenie miała produkcja żelaza na bazie lokalnych złóż rudy. Dzięki narzędziom z żelaza rosła 
produktywność rolnictwa i możliwość zapewnienia żywności większej liczbie ludzi. Znaczne korzyści przynosił handel żelazem, złotem i tekstyliami. Dzięki drodze wodnej, jaką był Nil, Meroe mogło wysyłać towary pochodzące z głębi Afryki aż do basenu Morza Śródziemnego. Dopiero w IV w. miasto stopniowo traciło na znaczeniu, a jego ostateczny upadek spowodowała inwazja wojsk Aksum. Przypuszcza się, że przyczyną upadku Meroe mógł być splot okoliczności takich jak: odcięcie od szlaków handlowych, klęska ekologiczna wywołana wycięciem lasów na potrzeby hutnictwa i jednoczesne zagrożenia ze strony sąsiednich krajów.

Miasto Meroe miało formę nieregularną i otoczone było murami, których szerokość wynosiła od 3,5 do 5,5 m. Mury budowano z kamiennych bloków bez zaprawy. W wyniku prac archeologicznych odsłonięto szereg świątyń, w tym świątynię Amona, tzw. łaźnie królewskie oraz nekropolie w tym nekropolię królewską z piramidami. Ogólnie kultura Meroe charakteryzowała się licznymi wpływami egipskimi nakładającymi się na rodzime tradycje.

Między XI a XV w. na południu Afryki rozwinęło się Wielkie Zimbabwe - silny ośrodek miejski będący stolicą utworzonego przez plemię Shona królestwa Mwene Mutapa. Miasto znajdowało się ok. 250 km na wschód od współczesnej stolicy Zimbabwe - Harare. Ruiny miasta do dziś robią ogromne wrażenie. Na ich podstawie można sądzić, że miasto składało się z trzech głównych części (Hull 1976, s. 4). Pierwszą część stanowi tzw. Great Enclosure (Wielkie Ogrodzenie) będące dużym obszarem w kształcie elipsy, której granicę wyznacza potężny mur o obwodzie $244 \mathrm{~m}$. Mur ten zbudowano z prostokątnych granitowych bloczków, które starannie dopasowano, co umożliwiło budowanie bez użycia zaprawy. Wewnątrz znajdują się kamienna wieża w formie stożka i pozostałości chat. Drugą część stanowiły rozmieszczone w dolinie wokół Wielkiego Ogrodzenia strukturyę, które można określić jako dzielnice mieszkalne w formie mniejszych ogrodzeń otaczających zgrupowania chat. Trzecim obszarem było położone na wzgórzu centrum ceremonialne. Materiałem, z którego budowano chaty, była mieszanka mułu, żwiru i ziemi z kopców termitów. Trzeba dodać, że badacze nie są zgodni co do przeznaczenia i funkcji poszczególnych budowli. Miasto zostało porzucone ok. roku 1450.

Charakterystyczne cechy tradycyjnych afrykańskich ośrodków miejskich wykazywały miasta-państwa ludu Hausa w Afryce Zachodniej. Obszar kulturowy Hausa, którzy przeszli na islam, rozwijał się w dłuższym okresie od połowy XV w. do początków wieku XIX. Centrum każdego miasta-państwa stanowiło birane (główny ośrodek), które było zlokalizowane w miejscu zasobnym w wodę, charakteryzującym się ogólnie dobrymi warunkami dla rozwoju rolnictwa (Kaplan, Wheeler, Holloway 2004, s. 437). Ważnym czynnikiem lokalizacji była możliwość pozyskiwania rudy żelaza. Najbardziej znanym przykładem takiego ośrodka było Kano. Miało formę nieregularnego owalu otoczonego wałem ziemnym o długości $24 \mathrm{~km}$. Na tym obszarze (od 30 do $40 \mathrm{~km}^{2}$ ) znajdowały się miasto, wioski i tereny rolnicze, a także wzgórza z pokładami rudy żelaza. W mieście znajdowały się: meczet, plac targowy z ciągami handlowymi i rozmieszczone wokół warsztaty rzemieślnicze. Tereny mieszkalne składały się z wyodrębnionych wspólnot 
(compounds), wewnątrz których znajdowała się grupa chat zbudowanych z mułowych cegieł. Formy przestrzenne wiązały się z patriarchalnym systemem społecznym. Każdą tego typu jednostkę zamieszkiwała duża, zarządzana przez patriarchę rodzina składająca się z jego żon, nieżonatych synów i niewolników. W ramach otoczonego wałem kompleksu mieszkało ok. 50 tys. ludzi.

W zachodniej części Afryki nad rzeką Niger przez długi czas rozwijały się Timbuktu i Djenne - dwa ważne ośrodki na biegnącym przez Saharę i dalej na południe szlaku handlowym. Ośrodek w Djenne powstał w połowie IX w., a założone przez Tuaregów Timbuktu - na przełomie XI i XII w. W wieku XIV oba miasta znajdowały się w obrębie wpływów Imperium Mali, a w roku 1468 zostały przejęte przez Imperium Songhai. Timbuktu i Djenne przetrwały upadek państwa Mali i rozwijały się dalej jako ośrodki handlu w ramach innego państwa. Wiek XVI to okres największego rozkwitu obu miast. Niger jako droga transportowa łączył dwa niezwykle istotne szlaki. Tą drogą przez Timbuktu i Djenne przewożono na południe sól wydobywaną na Saharze (w Taghaza). Jednocześnie przez oba miasta transportowano złoto z położonych na południu rejonów przy granicy strefy lasów w kierunku północnym przez Saharę.

W wyniku pokonania armii Songhai przez Maroko w 1591 r. oba handlowe ośrodki znalazły się pod władzą sułtana Maroka. Miasta funkcjonowały nadal, ale okres świetności miały już za sobą. Z dziewiętnastowiecznych opisów wynika, że Djenne zabudowane było głównie jednokondygnacyjnymi domami z cegieł suszonych na słońcu. Miasto było otoczone wałem ziemnym z kilkoma bramami. Stare miasto w Djenne, podobnie jak w Timbuktu, znajduje się obecnie na liście Światowego Dziedzictwa UNESCO.

Pierwszymi przybyszami z Europy, którzy pojawili się na wybrzeżach Afryki Subsaharyjskiej pod koniec XV w., byli Portugalczycy, którzy w wyniku kolejnych wypraw opłynęli Afrykę, dotarli do Indii i w konsekwencji aż do początku XVII w. zajmowali dominującą pozycję w europejskim handlu i kontaktach z Afryką.

Portugalski żeglarz Vasco da Gama był pierwszym Europejczykiem, który w 1498 r. przybył do Mombassy stanowiącej od ok. XI w. ważny ośrodek kupców arabskich na wschodnim wybrzeżu Afryki. W kolejnych latach Portugalczycy kilkakrotnie próbowali opanować miasto, co udało się ostatecznie w 1589 r. Cztery lata później zbudowali istniejący do dziś Fort Jesus. Położoną na zachodnim wybrzeżu kontynentu Luandę założyli w 1579 r., a na położonym od wschodniej strony Zanzibarze osiedlili się w roku 1583.

W Afryce Zachodniej od początku XVII w. Anglicy interesowali się Złotym Wybrzeżem, a u ujścia rzeki Senegal pojawiło się francuskie osadnictwo. Rok 1652, kiedy wyprawa pod wodzą Jana van Riebecka dotarła do Zatoki Stołowej i kiedy założony został Kapsztad (Cape Town), był początkiem obecności Holendrów w Afryce Południowej.

Europejczycy budowali na wybrzeżach Afryki niewielkie forty i osiedla głównie o wojskowym charakterze oraz punkty wymiany handlowej. Ośrodki te powstawały często w pobliżu istniejących osiedli miejscowej ludności, które stanowiły źródło zaopatrzenia. Oprócz tego, że funkcję militarną związaną z ochroną morskich szlaków komunikacyjnych wzdłuż wybrzeży były to ośrodki handlu niewolnikami i eksportu surowców. 
Wpływ Portugalczyków widoczny jest w ośrodkach miejskich powstających w tym czasie w różnych częściach Afryki. Jednym z przykładów może być Mbanza Kongo (na terenie dzisiejszej Angoli), które stanowiło stolicę silnego państwa znajdującego się na południe od rzeki Kongo (Freund 2007, s. 8). Od XV w. był to ośrodek handlu z Portugalczykami (szczególnie handlu niewolnikami). W usytuowanym na płaskowyżu mieście powstawały budynki w stylu europejskim, których budową początkowo kierowali Europejczycy. W późniejszym okresie miejscowi rzemieślnicy przyswoili sobie nowe techniki budowlane. Miasto zbudowane przez Portugalczyków nazwano São Salvador, był to nieduży, otoczony murami ośrodek z placem, katedrą i pałacem zamieszkany przez przybyłych z Portugalii kupców, a także księży i zakonników. Afrykańskie Mbanza Kongo składało się z ogrodzonych gospodarstw, między którymi biegły wąskie uliczki. W gospodarstwach uprawiano rośliny i hodowano zwierzęta, tak więc formy miasta i wsi przenikały się, co było charakterystyczne dla urbanizacji wielu regionów Afryki.

We wschodniej części Afryki przez ok. 250 lat bardzo ważnym ośrodkiem był Gondar założony w 1636 r. przez cesarza Etiopii Fasilidesa, który usunął portugalskich jezuitów, przywracając w kraju Koptyjski Kościół Ortodoksyjny jako Kościół etiopski. Będąc stolicą władców Etiopii, Gondar stał się ważnym centrum politycznym, handlowym i kulturalnym, do którego przybywali artyści, kupcy i podróżnicy z Europy i Bliskiego Wschodu. Najbardziej charakterystycznymi elementami zabudowy były pałace zbudowane przez Fasilidesa i jego następców. Centralną część stanowi Fasil Ghebbi - otoczony kamiennymi murami kompleks, na który składa się: sześć ufortyfikowanych kamiennych pałaców, kościół z końca XVII w., a także zbiornik określany jako Fasilidas Bath. Szczególnie imponujące są pozostałości zamku Fasilidesa. Wiele budowli, jak biblioteka, kościoły i inne obiekty, nie zachowało się do naszych czasów. Cechy architektury pozwalają mówić o stylu Gondar, w którym widoczne są wpływy portugalskie, indyjskie i miejscowe tradycje wywodzące się z czasów Aksum.

Uogólniając, trzeba zaznaczyć, że podobnie jak w innych regionach świata przyczyną powstawania miast na obszarze Afryki Subsaharyjskiej była potrzeba wypełniania różnych funkcji. Powstawały miasta ceremonialne, które były ośrodkami duchowymi - jak Ife dla ludu Yoruba. Powstawały miasta będące głównie ośrodkami władzy, z których zarządzano określonym terytorium. Wiele miast rozwinęło się w oparciu o funkcję handlową jako ośrodki wymiany towarów pochodzących z różnych regionów. Miasta tego typu powstawały często na granicy dwóch stref geograficznych (granica pustyni, granica lasów tropikalnych itp.). W większości przypadków, jak wszędzie, rozwijały się ośrodki wielofunkcyjne. Kumasi czy Benin były centrami politycznymi, duchowymi, kulturalnymi i handlowymi. Wielkie Zimbabwe powstało jako centrum rytualne, ale stało się też centrum politycznym i handlowym (Hull 1976, s. 121).

Miasta Afryki przed okresem kolonizacji wbrew niektórym opiniom nie były, jak zaznacza R.W. Hull, chaotyczne i bezplanowe. Ich układy przestrzenne wyrażały określone relacje społeczne, religijne i etniczne. Podstawową jednostką w sensie społecznym i ekonomicznym była rodzina, co widoczne było w przestrzennym podziale osiedla. 
W planie ośrodka wyraźnie zaznaczało się centrum, co szczególnie uwidacznia się w układzie miast ludów Joruba i Hausa (na terenie Nigerii), gdzie wszystkie drogi w osiedlu prowadziły do centralnie położonego pałacu i sąsiadującego z nim targowiska, tworząc układ promienisto-koncentryczny. Wspólnoty rodzinne znajdowały się w różnej odległości od centrum w zależności od pozycji społecznej głowy rodziny. W ważnych centrach ceremonialnych i politycznych elementem struktury przestrzennej była szeroka droga procesyjna i miejsce przed pałacem, gdzie odbywały się oficjalne ceremonie.

Czasem układ osiedla miał formę zbliżoną do szachownicowego, jak w Benin, Abomey czy Kumasi. Również kilka przedkolonialnych ośrodków na terenie dzisiejszego Senegalu miało ortogonalny plan na długo przed przybyciem Europejczyków. Ortogonalny plan na obszarze Senegalu pojawiał się w dwóch typach osiedli - w stolicach królewskich i osiedlach zakładanych przez islamskich duchownych (Ross 2017, s. 112). Centrum układu miasta królewskiego była siedziba władcy przy głównym placu publicznym. Istnieją ośrodki, które do czasów współczesnych zachowały elementy prostokątnej siatki ulic. Należą do nich Kahone, które było stolicą jednego z królestw między XVI a XIX w., a także Diakhao, na którego głównym placu do dziś dnia odbywają się publiczne uroczystości. W Lambaye, które też pełniło rolę stolicy, plan ortogonalny z centralnym prostokątnym placem ma zarówno główny ośrodek, jak i otaczające go mniejsze osiedla (ryc. 2). Praktycznie każde osiedle miało plac, który stanowił centrum - w sensie przestrzennym i społeczno-politycznym.

W wieku XVII istotną rolę w życiu społeczności zamieszkującej Senegambię zaczęli odgrywać muzułmańscy duchowni. Często byli powiązani z dworami królewskimi,

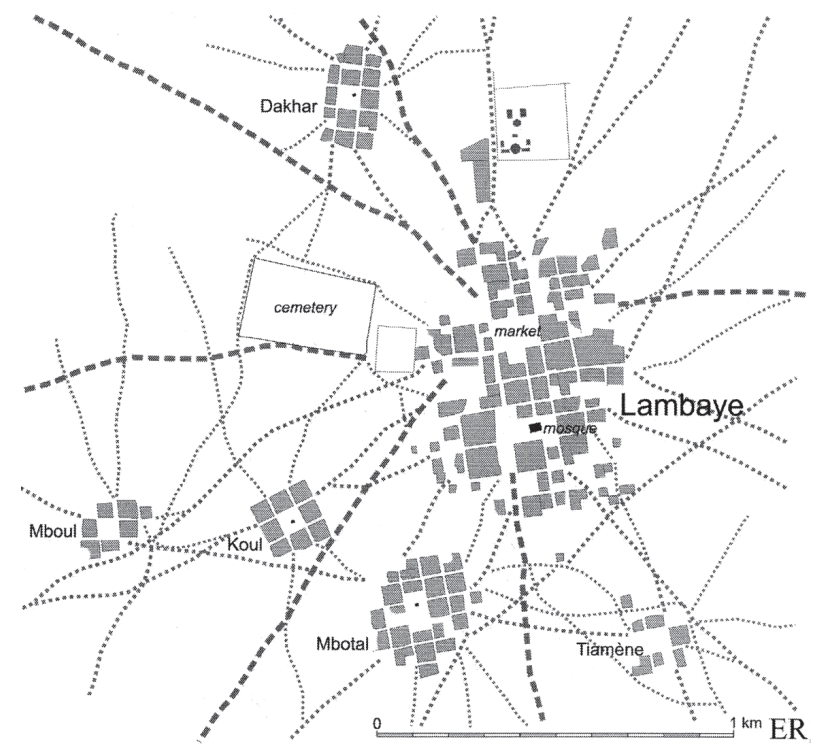

Ryc. 2. Plan miasta królewskiego Lambaye Źródło: Ross 2017, s. 113. 
gdzie pełnili różne funkcje - prawników, dyplomatów czy pisarzy. Duchowni ci zaczęli budować własne osiedla, które miały określony poziom autonomii w stosunku do władzy lokalnego króla. Ośrodki te często charakteryzowały się planem ortogonalnym podobnie jak stolice królewskie, przykładami centrów o takiej formie są Ngalik i Ndanq (ryc. 3). Założyciele obu tych ośrodków byli związani z dworem władców królestwa Kayor.

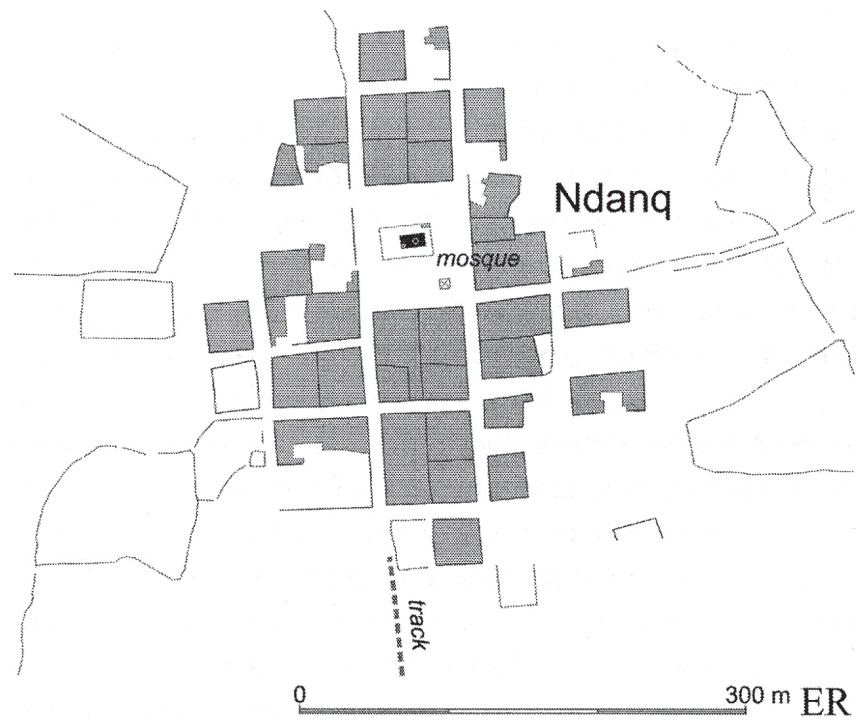

Ryc. 3. Plan Ndanq - ośrodka założonego przez duchownych islamskich Źródło: Ross 2017, s. 116.

W społecznościach mniej scentralizowanych (jak Ibo) siatka ulic była bardziej nieregularna, tworząc rodzaj labiryntu.

Kończąc ten fragment, chciałbym przytoczyć stwierdzenie R.W. Hulla, który uważa, że afrykańskie miasta i miasteczka odgrywały istotną rolę w sensie funkcjonalnym, wizualnym i duchowym. Symbolizowały one nie tylko stosunek człowieka do bliźniego i kosmosu, ale także przystosowanie się człowieka do środowiska naturalnego. Zamiast podbijać i niszczyć naturę, budowniczy afrykański czcił ją i uzupełniał (Hull 1976, s. 127).

\section{Rozwój miast na obszarze Afryki Subsaharyjskiej w czasach kolonizacji europejskiej}

Typowe miasta kolonialne powstały w Afryce stosunkowo późno. Okres pełnej kolonizacji Afryki trwał od końca XIX w. do roku 1960, ale przyczółki kolonizacji europejskiej powstały znacznie wcześniej.

O podziale kontynentu afrykańskiego między mocarstwa europejskie zadecydowano na konferencji w Berlinie w 1880 r. Był to początek procesu kolonialnej urbanizacji Afryki. 
Miasta istniejące przed okresem kolonialnej urbanizacji znalazły się w nowej sytuacji, przy czym tempo i stopień ich przekształcania były zróżnicowane. Można wskazać na przykłady silnych i ukształtowanych w okresie prekolonialnym ośrodków, które mimo zmian zasadniczo zachowały swój charakter (przykładem takiego miasta jest Ibadan w Nigerii). Niejednokrotnie zbudowanie nowego przedmieścia o charakterze europejskim obok istniejącego ośrodka prowadziło do powstania miasta dualnego, składającego się z części europejskiej i starszej, tradycyjnej części zamieszkanej przez miejscową ludność. W wielu przypadkach dzielnica europejska stopniowo zdominowała istniejący wcześniej ośrodek, który stawał się marginalną częścią nowego miasta. Czynnikiem lokalizacji nowego miasta mógł być istniejący wiejski ośrodek targowy.

Szereg zastanych ośrodków miejskich utracił podstawy egzystencji. Narzucone przez mocarstwa kolonialne nowe granice polityczne i nowy układ linii transportowych doprowadziły do zniszczenia wielu tradycyjnych szlaków handlowych i upadku położonych przy nich miast.

Zróżnicowanie formy i struktury nowo budowanych przez Europejczyków miast było rezultatem oddziaływania wielu czynników, takich jak: różne tradycje planowania miast w krajach europejskich, system zarządzania kolonią, a także lokalne uwarunkowania.

W pierwszym okresie, czyli pod koniec XIX w. i na początku XX, za realizację planu urbanistycznego nowego ośrodka odpowiadały władze wojskowe, później funkcje te przejęła administracja kolonialna. Europejscy planiści i architekci mieli tu większą swobodę w projektowaniu niż w swoich krajach (Silva 2017, s. 9).

Podstawową zasadą, której podporządkowano planowanie urbanistyczne miasta kolonialnego, była segregacja przestrzenna różnych, w sensie etnicznym i kulturowym, grup ludności. W pierwszym rzędzie dążono do oddzielenia ludności europejskiej od miejscowej. Tłumaczono to głównie względami zdrowotnymi i potrzebą zabezpieczenia ludności europejskiej przed chorobami tropikalnymi, takimi jak malaria czy żółta febra. Segregację uzasadniano też rozwijanymi w tamtych czasach teoriami dotyczącymi rozwoju ras i kultur.

Dzielnice europejskie oddzielone były od obszarów zamieszkanych przez miejscową ludność barierami naturalnymi, np. rzeką lub pasmem wzgórz. Czasem taką barierę stanowiły linia kolejowa lub tereny wojskowe. Jednocześnie ludność miejscowa była potrzebna w europejskich dzielnicach jako robotnicy budowlani czy służba domowa. Starano się więc, by była to jedynie obecność czasowa.

Plan urbanistyczny podkreślał różnice i społeczną nierówność między Europejczykami a miejscową ludnością. Dzielnicę europejską lokalizowano na terenie o najkorzystniejszych warunkach do zamieszkania, często na terenach wyżej położonych. Dzielnica ta była zwykle starannie zaplanowana, z regularną siatką ulic, kościołem, budynkami administracji i domami mieszkalnymi często nawiązującymi do stylu panującego w kraju, z którego przyjechali osadnicy.

Segregacja w przestrzeni miasta realizowana była bezpośrednio przez zapisy planu i wydzielanie odpowiednich stref a także w sposób pośredni przez wprowadzanie określonych standardów w budowaniu domów. Wymóg zastosowania odpowiednich 
materiałów budowlanych lub zakaz stosowania innych wykluczały możliwość osiedlenia się afrykańskiej ludności w dzielnicy białych mieszkańców (Jones 2011, s. 8).

Dzielnice ludności miejscowej rozwijały się najczęściej spontanicznie, na ogół bez regularnego planu. Do miasta przybywali ludzie z różnych stron kolonii należący do różnych plemion. W ten sposób tworzyły się dzielnice o charakterze etnicznym, co do dziś widoczne jest w strukturze społeczno-przestrzennej wielu miast afrykańskich.

Porównanie przestrzennego układu miast w koloniach brytyjskich i francuskich wskazuje na wpływ systemu zarządzania kolonią. W odróżnieniu od miast budowanych przez Francuzów ośrodki w koloniach angielskich cechuje mniejsza intensywność zabudowy i mniejsza regularność siatki ulic. Brytyjczycy na ogół nie zarządzali bezpośrednio skolonizowanymi terytoriami, pozostawiając formalną władzę lokalnym przywódcom. W takiej sytuacji mniej było centralnych regulacji dotyczących planowania miasta i niejednokrotnie miasto rozwijało się bez generalnego planu. Trzeba jednak zaznaczyć, że plany nowych ośrodków i dzielnic budowanych przez Brytyjczyków pozostawały pod widocznym wpływem idei miasta-ogrodu E. Howarda.

Francuzi zarządzali miastami w Afryce w sposób bezpośredni i bardziej scentralizowany. W koloniach francuskich miasta charakteryzowały większa regularność planu i większy poziom intensywności zabudowy, co prowadziło do powstawania bardziej zwartych zabudów. Dobrym przykładem jest porównanie sieci dróg Bamako (Mali) i Akry (Ghana), które na początku XX w. miały podobną liczbę ludności (ok. 1618 tys.). W zarządzanym przez Francuzów Bamako już w 1894 r. przygotowano plan sieci dróg, zastępując istniejącą spontanicznie rozwiniętą i nieregularną siatkę ulic typowym układem szachownicowym. Akra pod panowaniem brytyjskim nie miała generalnego planu aż do roku 1945 (Baruah, Henderson, Peng 2017, s. 17). Wynikające stąd różnice w planie sieci dróg obu miast widoczne są do czasów współczesnych.

Niewątpliwie okres kolonialny w Afryce był czasem przyspieszonej urbanizacji, podporządkowanej interesom państw kolonialnych. Podstawą rozwoju ludnościowego i ekonomicznego, a co za tym idzie - przestrzennego - większości ośrodków był wywóz zasobów naturalnych i produktów rolniczych do metropolii. Funkcja produkcyjna jako podstawa rozwoju pojawiała się rzadziej, głównie w miastach położonych w strefie wydobycia miedzi. W sytuacji gdy podstawową rolę odgrywał wywóz afrykańskich zasobów do Europy, najszybciej rozwijały się położone na wybrzeżach miasta portowe, które stały się ośrodkami dominującymi w systemie osadniczym poszczególnych kolonii. Budowane przez Europejczyków linie transportowe służyły przewozowi zasobów naturalnych i płodów rolnych z wnętrza kontynentu do ośrodków portowych. Ośrodki te stały się celem masowej migracji ludności wiejskiej z terenu kolonii, przyciągając jednocześnie przybyszów z Europy, którzy widzieli możliwość znalezienia pracy i robienia korzystnych interesów.

Obszarem szybkiej urbanizacji była Afryka Południowa, szczególnie po odkryciu i rozpoczęciu eksploatacji złota i diamentów. Z eksploatacją złota związana jest historia miasta Johannesburg, które zostało założone w 1886 r. i stało się ośrodkiem przyciągającym migrantów z różnych regionów świata. Miasto rozwijało się szybko 
i raczej chaotycznie, ale po 10 latach liczyło już 100 tys. mieszkańców. Struktura etniczna była zróżnicowana. Odpływ czarnej ludności z miasta w czasie wojen burskich (między Brytyjczykami i potomkami osadników holenderskich) i brak rąk do pracy spowodowały sprowadzenie robotników z Chin, którzy zostali na stałe w Johannesburgu, tworząc społeczność. Po pokonaniu Burów i zajęciu Afryki Południowej przez Brytyjczyków w 1902 r. miejscowa biała ludność domagała się zachowania zasad ostrej segregacji rasowej i wręcz budowania odrębnych ośrodków dla ludności czarnej. W 1904 r. Johannesburg liczył ok. 160 tys. mieszkańców, z czego połowę stanowili biali. W tym samym czasie powstało osiedle robotnicze przy kopalni, które dało początek Soweto - wielkiej dzielnicy czarnej ludności. W latach 50. XX w. Soweto rozbudowano zgodnie z zasadami brytyjskich New Towns, planując ciągi indywidualnych domów na działkach określonej wielkości. Do Soweto przeniesiono wówczas ludność ze slumsów otaczających Johannesburg.

W innych częściach Afryki Subsaharyjskiej proces urbanizacji postępował z różnym nasileniem. W centralnej części Afryki w roku 1880 Francuzi założyli miasto Brazzaville na południowym brzegu rzeki Kongo. Po drugiej stronie rzeki w 1881 r. Henry Morton Stanley założył Leopoldville (obecnie Kinshasa), które w 1926 r. zostało stolicą Konga Belgijskiego. W roku 1888 niemieccy handlarze kością słoniową założyli Yaounde (Kamerun). Na terenie górniczego obszaru związanego z wydobyciem miedzi w 1910 r. Belgowie zbudowali Elizabethville. Praktycznie wszędzie przestrzegano zasady przestrzennej segregacji rasowej tak jak w Leopoldville, które zaplanowano w układzie geometrycznym z uwzględnieniem podziału etnicznego i wprowadzono tzw. kordon sanitarny oddzielający dzielnice białej i czarnej ludności.

Na zachodzie Afryki szybko rozwijały się takie miasta jak Lagos, Akra czy Dakar. Wolniej rosła liczba ludności takich centrów w Afryce Wschodniej jak Kampala czy Dar es Salaam. Kampala istniała dużo wcześniej przed przybyciem Brytyjczyków jako stolica królestwa Buganda. W okresie kolonialnym straciła rangę stolicy, ale pozostała najważniejszym centrum gospodarczym Ugandy. W 1919 r. opracowano plan przestrzenny Kampali z uwzględnieniem segregacji jako podstawowej zasady. Dar es Salaam założone zostało w roku 1865 przez sułtana Zanzibaru, a od 1887 r. rozwijało się jako centrum Niemieckiej Afryki Wschodniej. Po przejęciu przez Brytyjczyków powstały zbudowane poza centrum miasta nowe dzielnice, odrębne dla Europejczyków i dla ludności afrykańskiej. Nowym ważnym centrum Afryki Wschodniej stało się założone w roku 1899 przez Brytyjczyków Nairobi. Miasto powstało w czasie budowy kolei łączącej Mombasę z Ugandą. W 1905 r. Brytyjczycy przenieśli z Mombasy do Nairobi stolicę swojego protektoratu.

Statystyki potwierdzają, że w okresie 60 lat (1900-1960) miał miejsce bardzo szybki rozwój ludnościowy największych ośrodków miejskich kolonialnej Afryki. Przykładowo liczba ludności Johannesburga wzrosła w tym okresie z ok. 100 tys. do ponad miliona, Akry (Ghana) z 18 tys. do 491 tys., Leopoldville z 5 do 420 tys., Dakaru (Senegal) z 18 do 383 tys., Lagos (Nigeria) - z 74 do 364 tys., Nairobi (Kenia) - z 12 do 267 tys., Luanda (Angola) - z 20 do 220 tys. (Freund 2007, s. 66). 


\section{Podsumowanie}

Studia nad procesami urbanizacji w Afryce Subsaharyjskiej w okresie przedkolonialnym i w czasach kolonialnych prowadzone przez badaczy z różnych krajów pozwalają na dokonanie pewnych uogólnień.

Tradycje cywilizacji miejskich na obszarze Afryki Subsaharyjskiej sięgają czasów starożytnych, jak Meroe (VIII w. p.n.e.) czy Aksum (V w. p.n.e.). W okresie przedkolonialnym w ośrodkach miejskich różnych regionów Afryki kształtowały się oryginalna forma i struktura przestrzenna wynikające z warunków i systemów społecznych. Jedną $\mathrm{z}$ charakterystycznych cech było przenikanie się formy miasta i wsi. Z pewnością nie były to miasta bezplanowe.

W okresie kolonialnym w Afryce po roku 1880 miał miejsce proces przyspieszonej urbanizacji, która jednak w pierwszym rzędzie wynikała z potrzeb i interesów mocarstw kolonialnych. Podstawową zasadą stosowaną przez administrację kolonialną w planowaniu miast była segregacja przestrzenna grup etnicznych. Starano się przede wszystkim oddzielić dzielnice ludności europejskiej od terenów zamieszkania ludności miejscowej. Zagospodarowanie przestrzenne miasta podkreślało nierówności między tymi grupami. Różnice między brytyjskim i francuskim systemem zarządzania koloniami są dostrzegalne w strukturze przestrzennej miast.

Sześćdziesięcioletni, a więc w skali historycznej stosunkowo krótki okres kolonizacji Afryki i europejskiej urbanizacji kontynentu pozostawił trwałe ślady widoczne zarówno $\mathrm{w}$ rozmieszczeniu miast, charakterze sieci osadniczej - z modelem primate city w większości krajów - jak i w strukturze przestrzennej ośrodków miejskich.

\section{Bibliografia}

Baruah N.G., Henderson J.V., Peng C., 2017, Colonial legacies: Shaping African cities, "SERC Discussion Paper" 226.

Freund B., 2007, The African city, a history, Cambridge University Press, Cambridge.

Hull R.W., 1976, African cities and towns before the European conquest, Norton, New York-London.

Jones B.G., 2011, Civilising African cities: International housing policy from colonial to neoliberal times, 2012, "Journal of Intervention and Statebuilding" vol. 6, Iss. 1.

Kaplan D.H., Wheeler J.O., Holloway S.R., 2004, Urban geography, John Wiley \& Sons, Hoboken.

Mehretu A., 1993, Cities of Sub-Saharian Africa, [w:] Brunn S., Williams J. (eds.), Cities of the world: World regional urban development, Harper Collins, New York.

Ross E., 2017, The grid plan in the history of Sengalese urban design, [w:] Silva C.N. (ed.), Urban planning in Sub-Saharian Africa, colonial and post-colonial planning cultures, Routledge, New York-London.

Silva C.N., 2017, Urban planning in Sub-Saharian Africa, an overview, [w:] Silva C.N. (ed.), Urban planning in Sub-Saharian Africa, colonial and post-colonial planning cultures, Routledge, New York-London.

Windmuller-Luna K., 2015, Monumental architecture and stelae of the Aksumite Empire, "Heilbrunn Timeline of Art History” (April 2015), http://www.metmuseum.org/toah/hd/aksu_3/hd_aksu_3.htm (dostęp 10 października 2018). 